\title{
An Insight into the Influence of Corona Virus Surge on Nigerian Economy
}

\author{
Sunday Amos ADEUSI ${ }^{1 *} \quad$ Omoniyi Jacob ENIOLA ${ }^{2} \quad$ Adesanmi Timothy ADEGBAYIBI, Ph.D ${ }^{1}$ \\ Sunday Rufus OLORUNTOBA ${ }^{1}$ \\ 1.Department of Accounting, Adekunle Ajasin University, Akungba Akoko Ondo state, Nigeria \\ 2.Department of Accounting, Joseph Ayo Babalola University, Ikeji Arakeji, Osun State, Nigeria
}

\begin{abstract}
The study explored the emergence of a novel virus disease called covid-19 that is ravaging, devastating both human health and global economy and dissect vis-à-vis Nigerian economy. Ordinary Least Square Regression (OLSR) was used to analyse Total Nigeria Confirmed Cases (TNCC), Total Africa Confirmed Cases (TACC) and Total Global Confirmed Cases (TGCC) as exogenous variables while the endogenous variables are market capitalisation, (mcapt), foreign exchange rate of US-Dollar to Naira (usnaira) and crude oil price per day (copd) for period of 182 days. The result revealed that covid-19 pandemic has had an adverse impact on market capitalisation, exchange rate and crude oil price and Nigerian economy as a whole. We recommend that bailout funds should be made available to stakeholders in the capital market, funds in foreign exchange reserve accounts should be used to hedge foreign exchange fluctuations and funds in excess crude oil accounts should be used to cushion the effect of fall in crude oil price.
\end{abstract}

Keywords: COVID-19, Foreign exchange rate, Crude oil, Market capitalisation

JEL: D 53, F 31, I 15

DOI: $10.7176 /$ RJFA/11-18-02

Publication date:September $30^{\text {th }} 2020$

\subsection{INTRODUCTION}

Coronavirus popularly referred to as COVID-19 is a novel virus that originated from the city of Wuhan, China, (with a population density of more than 10 million people), in December, 2019. COVID-19 pandemic has thrown a deadly blow on human health globally with over one million fatalities across borders. Global integration aided prompt spread of the pandemic around the globe in the first quarter of 2020 with its footprints on over 200 countries of the world - developed, developing and under-develop economies. This informed declaration of the outbreak as pandemic in $30^{\text {th }}$ January 2020 by the World Health Organisation (WHO).

This pandemic disrupted economies of nations, putting it to a standstill with attendant effects on human health, and externalities on global economic fortunes. The economic effects of COVID-19 on global economy could not be quantified because it was multifaceted and had an exponential progression in nature. These are evident in drastic drops in the US stock market, the Japanese stock market, Nigerian stock market (Takahashi \& Yamada, 2020). Again, part of the externalities of the COVID-19 control measures such as lockdown and social distancing are job loss, suspension of cross-border travels and business, production shutdown, loss of customers, stock market downturn to mention a few.

The core of this study is to examine the spillover effects of covid-19 on the Nigeria economy. The specific objectives are to examine the effect of covid-19 on the market capitalisation of the Nigerian stock market; the foreign exchange rate of US-dollar to Naira, and to ascertain its effect on the Nigerian crude oil price.

The study is organised thus, section one presents introduction to the study, section two deals with the literature review and hypotheses development, methodology is showcased in section three, data analysis and discussion is housed in section four and the last section is on conclusion and recommendations.

\subsection{LITERATURE REVIEW AND HYPOTHESIS DEVELOPMENT 2.1 COVID-19 Pandemic and Global Economy}

COVID-19 pandemic, also known as the coronavirus disease is a recent and on-going pandemic caused by virus resulting to severe acute respiratory syndrome. The first confirmed case in relation to the pandemic in Nigeria was announced on the 27th February, 2020, when an Italian citizen arrived in the country through Muritala Muhammad International Airport Lagos, and got tested positive for the virus.

On the $28^{\text {th }}$ January, 2020, the Federal government of Nigeria assured citizens of the country of her readiness to strengthen surveillance at the five International Airports in Nigeria to prevent the spread of coronavirus. The government announced the airports as Enugu International Airport, Aminu Kano International Airport Kano, Muritala Muhammend International Airport Lagos, International Airport Port Harcourt Rivers and Nnamid Azkiwe International Airport Abuja (Premium Time, 29 January, 2020). The Nigeria Centre for Disease Control (NCDC) also announced on the same day that they had already set up coronavirus group and was ready to activate its incident system if any case emerged in Nigeria (Odunsi, 2020). 
On the $31^{\text {st }}$ January 2020, following the outbreak of COVID-19 pandemic in Mainland China and its spread to other countries worldwide, the federal government of Nigeria set up a Coronavirus preparedness Presidential Task Force (PTF) to proactively initiate ideologies that assist in mitigating the impact of the virus if it eventually spread to the country (Ifijeh, Martins, 31 January 2020). On the same day, the World Health Organization listed Nigeria among other 13 African countries identified as country with high-risk for the spread of the virus (Ezigbo, Onyebuchi; Ifijeh, Martins, 1 February 2020).

The advent of the covid-19 pandemic in the human race at this time has impacted negatively the advanced clans of the economy, while devastating effects on global economics are now enormous. The current health challenges globally have propelled different scholars to dissect the effects in divergent areas of global economic sectors. Since the outbreak of covid-19 has resulted in global economic crisis, this economic period could be equally named as coroeconomy regime. The novel virus has the capacity to devastate human body systems directly and at the same time denigrates global economy indirectly. Since the emergence of the pandemic, it has common externalities on the socio-economic wellbeing of global communities, either developed or developing. The experiences of the devastating effect of the coro-economic virus of the other clans economy have been scholarly dissected and are insightful beneath. Takahashi and Yamada (2020) examined series of factors responsible for Japanese stock returns downturns that started in the first quarter of 2020 of the period of covid-19. The effects of the novel virus on the US stock market, China stock market and Germany are very obvious and could not be easily erased from pandemic chronicles.

Albulescu (2020) affirmed that the COVID-19 has created fear of the uncertainty of the global economy that amplified global financial market volatility. At the same time, the price of crude oil reacted to COVID-19. When the World Health Organisation (WHO) announced monitoring report of 49 days of the existence of this pandemic, it prompted Saudi Arabia to flood the international crude oil market with oil. Against this backdrop, international crude oil price dropped by more than $20 \%$ in one single day. Hence, the pendulum of the price of crude oil at the international oil market swung between $\$ 11$ and $\$ 30$ per barrel which were far below a price as high as $\$ 64$ per barrel before the emergence of the pandemic.

The Tourism and Aeronautic industry in the Republic of China had a huge contributing influence on the nation's economy. The world's most booming Tourism and Aeronautics industry is situated in China and is considered the world's most viewed inbound and outbound tourism market. The Chinese tourism industry generates whooping some of CN¥5,128 billion, but the advent of the novel Coronavirus has disrupted and impacted the industry negatively (Hoque, Shikha, Hasanat, Arif, \& Hamid, 2020).

\section{Nigerian Economy}

Nigeria economy, and Nigerians business activities before crude oil glut was predominantly Agro allied based business that had multifaceted businesses, if well developed. The failure of the government of Nigeria to harness quantum of the great potential in agriculture has negatively affected and spelt doom on the Nigeria economy under this pandemic situation. Over reliance on crude oil as the major driver of the Nigeria economy has made the Nigerian economy susceptible to any forms of global economic shocks emanating from global change in crude oil price.

The direction of the Nigerian economy and annual budget estimate are functions of the economic behaviour of variables like global crude oil price, foreign exchange rate, stock prices etc. The projection of the International Monetary Fund (IMF) for Nigerian economy has been slashed from economic growth of $2 \frac{1}{2} \%$ to $2 \%$ for the 2020 fiscal year. This is as a result of COVID-19 pandemic outbreak. The Nigerian economy is the biggest producer of crude oil in the sub-Saharan West African nations that the economy depends solely on crude oil for $90 \%$ of its exports.

According to Maijama'a, Musa, Isah and Adamu (2020).

"The oil price shock due to the COVID-19 came as a great surprise to the Nigerian government and the impact has put significant strain on the budget and the currency and the government may have to adjust its 2020 budget, which was based on a crude price of $\$ 57$ a barrel according to the finance minister. Already, oil prices, which are the mainstay of the country are trading below the Federal Government's benchmark for the 2020 budget, thus posing a threat to the budget, which was signed into appropriation law 2020 Acts on the assumption of oil production of 2.18 million barrels per day with the price benchmark of $\$ 57$ per barrel”.

Based on this backdrop, the impact of coronavirus confirmed cases and fatalities on the Nigerian economy would be expected to be huge with attendant consequence of government inability to finance and implement the estimated capital and recurrent expenditure as contained in the 2020 appropriation Acts. Consequently, the aftermath of crash in international crude oil prices would have led to downsizing estimated budget.

Furthermore, Nigerian economy is an import-oriented-economy, which makes it vulnerable to fluctuation in foreign currencies because Naira is a petrocurrency. These are economic barometers that determine, affect and could drain up excess crude oil account balance as well as account for provision of foreign exchange reserves. According to Maijama'a, Musa, Isah and Adamu (2020); 
The current position of Excess Crude Account balance, according to a statement from the Office of the Accountant General of the Federation, was put at $\$ 71.81 \mathrm{~m}$, while movement in reserves showed that the country's reserves stood at $\$ 36.37$ billion, down by $\$ 2.16$ billion from $\$ 38.53$ billion in which it opened the year 2020. Nigeria's foreign exchange reserves and the Central Bank of Nigeria set a $\$ 30$ billion foreign exchange reserves entry for devaluation. Nigeria is treacherously close. A slump in foreign reserves from $\$ 38$ billion to $\$ 30$ billion in Nigeria will occur just as dramatically. Nigeria's foreign exchange reserves are there to assist the Central Bank protect the Naira's value; the Central bank can sell foreign exchange reserves to purchase their local currencies in an effort to defend the currency's value. This action depends on the provision of foreign exchange reserves, and any action taken by $C B N$ might really provide an indicator to foreign investors of impending devaluation.

The sequence would be provoked if foreign shareholders begin to quit Nigerian equities and bonds all together. If the central bank plan fails and Nigeria runs tremendously low on foreign reserves, the Naira might decrease in value, permitting entrepreneurs to arbitrage. Nigeria's gross foreign exchange reserves are at the same level approximately $\$ 38$ billion as they were in 2014 and 2015 years when oil prices as well fell sharply compared both periods with the $\$ 53$ billion in foreign reserves. Nigeria had in 2008, at the height of the international financial crisis, and that still incurred a serious economic charge on Nigeria"

In addition to the Nigerian economy's susceptibility to global economic variables volatility, the importers of Premium Motor Spirit (PMS) do largely require foreign exchange fluctuation hedged from the Central Bank of Nigeria which is called fuel subsidy. That is, the usual practice in Nigeria is that barrels of crude oil are exported as raw material to advanced economies, while the finished products are imported into the Nigerian economy by the business moguls.

The economic implication of this situation is that, Nigerian economy creating employment opportunities to the developed economies, where the percentage of unemployment rate is at barest minimum of single digit number. This practice dovetails into importation of unemployment because the finished crude oil products require no special value addition. Suppose the crude oil is refined in Nigeria, this would have created employment and thereby reduced the level of unemployment in the country which is already standing at $33 \%$.

\subsection{Development of Research Hypotheses}

\subsubsection{Impact of COVID-19 on the Volatility index (VIX) of Nigerian stock market}

The empirical evidences of the impact of COVID-19 on the Nigerian economy as well as other countries of the world have been documented by diverse school of thoughts (Alade et al., 2020; Onali, 2020; Nseobot et al., 2020).

Nseobot et al. (2020) ascertain the association between the novel coronavirus and situation analysis of Nigerian economy. The outcome of the investigation revealed that the indelible impact of novel coronavirus has long-run effect on the Nigerian economy which is statistically significant and negative in the area of economic stress and share prices.

Onali (2020) investigated the impact of coronavirus confirmed cases and associated deaths in the American stock market in order to verify changes in volume of trading at the floor of market and volatility expectations on the daily and weekly trading indexes. The study employed secondary data from 8 April to 9 April, 2020 and GARCH $(1,1)$ model was used to carry out comparative analysis among six other countries that COVID-19 affected. However, the results revealed that it has evidence of a positive impact for some countries. Vector Auto Regression models reported the number of deaths in France and Italy have inverse impact on the stock market returns and direct influence on VIX returns and concluded that Markov-switching model suggested that at end of February 2020 the result have negative influence on threefold increase on VIX stock market returns.

Yilmazkuday (2020) examined the consequence of COVID-19 pandemic confirmed cases in the USA on the VIX of S\&P 500 index. The outcome of the investigation was achieved by employing Structural Vector Autoregression model (SVAR) on daily January $31^{\text {st }} 2020$ and May $31^{\text {st }} 2020$. The empirical outcomes revealed that having $1 \%$ of an increase in the cumulative daily COVID-19 confirmed cases in America resulted in about $0.01 \%$ of a cumulative decrease in the S\&P 500 VIX and concurrently $0.03 \%$ of a decrease after a month.

Alade et al. (2020) examined the relationship between COVID-19 confirmed cases and the Nigerian stock market capitalisation. A 3-month secondary data used and analysed through Vector regression model shows that COVID-19 confirmed cases have mixed relationship with the Nigerian stock market equity capitalisation, while global confirmed cases depicts antithetic association with the market capitalisation, but both are not statistically significant.

Baker, Bloom, Davis, Kost, Sammon and Viratyosin (2020) pointed out that ere coronavirus outbreak, there were no contagious diseases that have devastated as a tsunami to USA stock market volatility. The outbreak of SARS 2003 epidemic and Ebola 2015 impacted modestly and short-lived on the VIX of the stock market. Bird flu and Swine flu just registered a mild influence of volatility, but COVID-19 pandemic drove the tremendous surge 
that led to the third highest stock volatility acme since 1900. They concluded that volatility peak is extraordinarily high and this has been triggered by COVID-19 development and the peak reached the fourth week of February 2020 .

Concisely, the influence of COVID-19 pendulum seems to have swung toward negativism in Nigeria context as the developing economy and Nigerian stock market are predominantly equities market based which is associated with propensity to react abnormally in case of sudden shock in the economy like the event of COVID-19. Hence, our hypotheses are stated in alternative form

Ha1: COVID-19 has statistically significant negative impact on the Nigerian economy.

\subsubsection{The causal effect of COVID-19 on the Nigerian Currency Foreign Exchange}

By nature, Nigeria economy has been described as an import-oriented economy. The economic implication of this type of economy is that such an economy is predisposed to the adverse effect of leading foreign currencies fluctuation. This has made monetary authorities in Nigeria, that is Central Bank of Nigeria $(\mathrm{CBN})$, and other financial institutions within the country put in place standing policies for importers to hedge them in case of uncertainty of currencies exchange fluctuations at the international market.

Exchange rate is the ratio at which naira currencies are being swapped with foreign currencies. When quantum quantities of naira currency is given in exchange of single foreign currencies. The economic implications is that naira is relatively weak. The purchasing power of such an economy has been eroded due to foreign exchange ratio, while foreign currency is stronger with corresponding high purchasing power as a result of appreciated foreign exchange ratio.

Historian-economist revealed that foreign exchange rate of naira in Nigerian economy was relatively stable between 1973 and 1979. During this period, the mainstream of Nigerian economy is majorly agricultural products which accounted for about $75 \%$ of the country's gross domestic product (Ewa, 2011). But due to the advent of crude oil, succession efforts by the government to ensure that a stable foreign exchange rate achieved had proved abortive. Rather, naira depreciated since the 1980s up till date, while the fluctuating rate has become unabated (Benson \& Victor, 2012).

Akinkunmi (2007) considered the causality of foreign exchange fluctuation and economic development in Nigerian economy. The result revealed that depreciation of the real foreign exchange rate stimulates internal kin competitiveness of domestic productivities and raises export in the economy and increased the cost of production, thereby redistributing income against the poor in the economy.

Jongbo (2014) investigated the interaction that subsist between the real exchange rate fluctuation and the industrial sector of the Nigerian economy in order to look at the lacuna. The effect of misalignment of real exchange rate was achieved with result revealing that real exchange rate play a significant role in reengineering the industrial productivity, and that accessibility of foreign exchange increase through contentious export drive from both oil and non-oil products will contribute tremendously to increase in industrial output.

Osigwe (2015) examined the influence of exchange rate unpredictability on crude oil price as well as performance of the economy. OLS of two stages was used to estimate the data. The result showed that the real exchange rate has a direct influence on economic performance of Nigeria and the same effect on the crude oil prices was positively influenced.

Villarreal-Samaniego (2020) explored the effect of COVID-19 in the first quarter of 2020 to find out the detrimental tsunami conditions of socio-economic wellbeing of five oil related countries with a view to examining the long and short term association between the exchange rate of two oil importing and three oil exporting countries' currencies with coronavirus confirmed cases as well as crude oil. The result of the ARDL estimator revealed that the relationship between COVID-19, exchange rate and the price of crude oil were inversely and significantly related. This serves as underpinning ground for a the second proposition stated as follow in the alternative form;

$\mathrm{Ha}_{2}$ : COVID-19 has statistically significant negative impact on the foreign exchange rate.

\subsubsection{The influence of COVID-19 Pandemic on the crude oil prices}

Nigerian economy is basically a mono-economy that depends solely on crude oil production as its main basis of income earnings capacity. The advent of coronavirus that tsunami the global economy deleteriously, the impact cannot be overemphasised. The marginal negative contagious nature of COVID-19 on human health was replicated on the global economy. Albulescu (2020) investigated the influence of COVID-19 on major numbers economies clan of crude oil prices. ARDL estimation was deployed to dissect daily reported confirmed cases of COVID-19 and its infectious trend globally and the attendant consequence on the crude oil prices in the world oil market. The result revealed a negative contiguous nature on the crude oil prices both in the short-run and long-run with attendant adverse effect on financial market volatility.

The investigation into COVID-19 and its associated effect on the crude oil prices as it affects United States of America economy policy uncertainty was carried out by Albulescu (2020b). ARDL model employed to find out the global confirmed cases of COVID-19 and the death ratio. But the outcome showed that the endogenous variables have no significant affluence on United States of America economy policy uncertainty, while the crude oil prices adverse effect dynamics led to increased USA economy uncertainty. 
Kingsly and Henri (2020) revealed that the emergence of COVID-19 pandemic especially in the China and European countries has drastically reduced the demand for crude oil as a result of the lockdown of manufacturing sectors which invariably had disrupted their marginal propensity to consume crude oil. As such, WTI and Brent light fell by $30 \%$ and $24.59 \%$ to $\$ 30$ and $\$ 31.13$ per barrel respectively on March 9,2020 .

Sharif Aloui and Yarovay (2020) examined the connectedness that subsist between oil prices volatility shock, geopolitical risk and stock markets and economic policy uncertainty as exogenous vis-à-vis COVID-19 pandemic. The wavelet-based granger causality tests and logic wavelet method were used to dissect US daily data. The result unveiled the exceptional impact of COVID-19 of both short-run and long-run crude oil volatility and other explanatory variables. In summary, crude oil prices fluctuation is critically influenced by the catalytic nature of COVID-19, hence, the hypothesis thus stated;

Ha3: COVID-19 has statistically significant negative impact on the crude oil prices

\subsection{METHODOLOGY AND RESULT PRESENTATION}

\subsection{Research Design and Data}

The study deployed quantitative and ex-post facto research design, quantitative in sense that all data used were numbers of confirmed case of covid-19 in the three territories (Nigeria, Africa, and Global) from $1^{\text {st }}$ January to $30^{\text {th }}$ June 2020. Ex-post facto, this means that the data were extracted from of existing records of Nigeria Centre for Diseases Control (NCDC), Africa Centre for Diseases Control and john Hopkins University. Purposive sampling technique was used in taken daily list of confirmed cases for 182 days. Autoregressive Integrated Moving Average (ARIMA) model was deployed because it was a model fitted to time series where it is evident of nonstationarity of set of data to be used or it can be applied to one or more times to eliminate the non-stationarity.

\subsection{Model specification and data analysis}

The study has three models in order to be able to achieve three stated objectives and stated hypotheses.

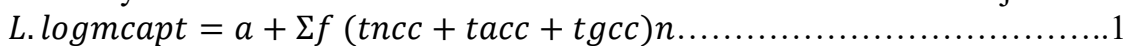

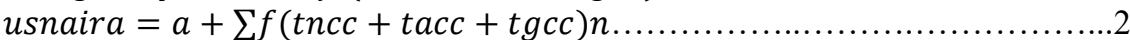

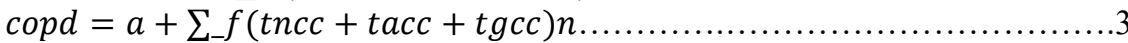

Where:

Explained variables are:

L. logmcapt: Market capitalisation

Usnaira: Exchange rate of us dollar to naira

Copd: crude oil price per day

Explanatory variables are:

Tncc : total Nigeria confirmed cases

Tacc : total Africa confirmed cases

Tgcc: total global confirmed cases

\subsection{DATA ANALYSIS AND DISCUSSION}

4.1 Descriptive analysis

Table 1: Descriptive statistics

\begin{tabular}{lclllllll}
\hline & $\mathbf{N}$ & \multicolumn{1}{c}{ Mean } & St.Dev & \multicolumn{1}{c}{ min } & \multicolumn{1}{c}{ max } & skewness & kurtosis & t-value \\
\hline Marketcapt & 182 & $1.31 \mathrm{e}+13$ & $1.27 \mathrm{e}+12$ & $1.08 \mathrm{e}+13$ & $1.53 \mathrm{e}+13$ & .155 & 2.006 & 138.337 \\
Usnaira & 182 & 376.466 & 11.901 & 361.29 & 391.64 & -.09 & 1.141 & 426.762 \\
Copd & 182 & 37.859 & 13.923 & 11.26 & 66.79 & .125 & 1.857 & 36.684 \\
Tncc & 182 & 3948.808 & 6604.838 & 0 & 25133 & 1.704 & 4.769 & 8.066 \\
Tacc & 182 & 59207.51 & 97536.98 & 0 & 396188 & 1.825 & 5.359 & 8.189 \\
Tgcc & 182 & 2400000 & 2970000 & 27 & $1.02 \mathrm{e}+07$ & 1.042 & 2.836 & 10.919 \\
\hline
\end{tabular}

Source: Authors' compilation (2020)

Table 1 shows the summary of the population parameters of the data used in the study. The market capitalisation (marketcapt) has the average of 13 billion with associated spread from the mean or the dispersion from the average was $\$ 12.7$ billion which are significantly higher than $\$ 12$.1billion and reported by Alade et al (2020) from the same stock market with the use of three month data. This means that the difference between average value and the standard deviation in this study was $¥ 0.3$ billion, it is good homage for the market. The economic implication of this is that, there would be no much shock that can affect the volatility index of the market, if unforeseen contingency happens.

The minimum and maximum value of marketcapt stood at 10 billiion and 15 billion respectively. While the marketcapt skewed positively of 0.55 with associated kurtosis value of 2.006 . Moreover, the $t-$ value of the marketcapt stood at 138.337. The t-value do revealing it support for the hypothesis of the population parameter, the greater the value of $t$, the greater the tendency to reject null hypothesis while lesser t-value revealed lesser 
tendency to reject null hypothesis.

The foreign exchange rate (usnaria) on the average stood at $\$ 1$ to $\$ 376.47$ with associated standard deviation of 11.90. This means that there is a great dispersion from the mean, with distance of 376.47 . This implies that any external force can bring great shock to the foreign exchange to fluctuate high at the detriment of naira currency. The minimum and maximum value stood at $\$ 361.29$ and $\$ 391.64$ respectively. Also the usnaria skewed negatively with associated kurtosis of 1.141 . The t-value of foreign exchange stood at 426.762 .

This value is greater than the average value of $\$ 376.466$. It is economically implied that foreign exchange rate is negatively impacted on the Nigerian economy. The average crude oil price per day stood at $\$ 37.86$ with associated standard deviation of $\$ 13.92$. The distance between the mean and standard deviation is $\$ 23.9$, this also implies that the distance is far from the mean that can cause shock the crude oil price by any exterior factors. The minimum and maximum values stood at 11.26 and $\$ 66.76$ correspondingly, with t-value of 36.68 , which suggested that crude oil price has an enormous adverse effect on Nigerian economy during the period under review.

The average of confirmed cases of covid-19 stood at 3,949 with a standard deviation of 6,605 , and the maximum and minimum numbers stood at 25,133 and 0 respectively. The figure of skewness and kurtosis stood at 1.704 and 4.769 respectively, which confirmed cases are positively skewed. The t-value is 8.066 .

The mean of confirmed cases of covid-19 in African and globally stood at 59,207 and 2,404,764 respectively and the associated standard deviations are 97,537 and 2,970,000 respectively for Africa and global. The minimum and maximum value for Africa and global are 0 and 396,188, 27 and 10,200,000. The confirmed cases of both global and Africa skewed positively with values of 1.042 and 1.025 respectively with associated kurtosis of 2.386 and 5.359 and respective value of t-value stood at 10.919 and 8.189 .

\subsection{Pairwise correlations}

Table 2: The data correlation matrix

\begin{tabular}{|c|c|c|c|c|c|c|}
\hline Variables & (1) marketcapt & $\begin{array}{l}\text { (2) } \\
\text { usnaira }\end{array}$ & $\begin{array}{l}\text { (3) } \\
\text { copd }\end{array}$ & $\begin{array}{l}(4) \\
\text { tnce }\end{array}$ & $\begin{array}{l}\text { (5) } \\
\text { tacc }\end{array}$ & $\begin{array}{l}(6) \\
\text { tgcc }\end{array}$ \\
\hline (1) marketcapt & 1.000 & & & & & \\
\hline \multirow[t]{2}{*}{ (2) usnaira } & $-0.613^{*}$ & 1.000 & & & & \\
\hline & 0.000 & & & & & \\
\hline \multirow[t]{2}{*}{ (3) copd } & $0.862 *$ & $-0.727 *$ & 1.000 & & & \\
\hline & 0.000 & 0.000 & & & & \\
\hline \multirow[t]{2}{*}{ (4) tnce } & -0.063 & $0.571^{*}$ & -0.075 & 1.000 & & \\
\hline & 0.398 & 0.000 & 0.313 & & & \\
\hline \multirow[t]{2}{*}{ (5) tacc } & -0.083 & $0.575^{*}$ & -0.093 & $0.998 *$ & 1.000 & \\
\hline & 0.265 & 0.000 & 0.210 & 0.000 & & \\
\hline \multirow[t]{2}{*}{ (6) tgce } & $-0.211^{*}$ & $0.751 *$ & $-0.282^{*}$ & $0.926^{*}$ & $0.923 *$ & 1.000 \\
\hline & 0.004 & 0.000 & 0.000 & 0.000 & 0.000 & \\
\hline
\end{tabular}

Source: Authors' Compilation (2020)

Table 2 presents the strength of interrelationship of the variables used in the study. The marketcapt has a strong and negative association with usnaria (-0.613), while crude oil price per day has a very strong and positive relation with marketcapt (0.862) and also has strong and negative relation with usnaria (-0.727). When the total Nigeria confirmed cases has loose and negative nexus with marketcapt $(-0.063)$ and has weak and positive association usnaria and lastly has loose and negative link crude oil price per day $(-0.075)$. The confirmed cases in Africa has loose and negative link with marketcapt (-0.083), while it has weak and positive association with usnaria (0.571) and also has loose and negative link with crude oil price per day and has very strong and positive connexion with Nigeria confirmed cases $(0.998)$. The global confirmed cases have weak and negative connection with marketcapt $(-0.211)$, but has strong and positive association with usnaria $(0.751)$ while its association with copd was weak and negative (-0.282). And lastly, global confirmed cases association with Nigeria and Africa confirmed cases were perfect and positive association (0.923). 
4.3 Inferential statistics

4.3.1 Regression results of Market capitalisation and Nigerian, Africa and Global covid-19 Confirmed cases Table 3

\begin{tabular}{|c|c|c|c|}
\hline VARIABLES & $\begin{array}{l}\text { (model 1) } \\
\text { L.logmcapt }\end{array}$ & $\begin{array}{l}\text { (model 2) } \\
\text { L.logmcapt }\end{array}$ & $\begin{array}{l}\text { (model 3) } \\
\text { L.logmcapt }\end{array}$ \\
\hline Tnce & $\begin{array}{l}-2.71 \mathrm{e}-07 \\
(4.81 \mathrm{e}-07)\end{array}$ & $\begin{array}{l}3.51 \mathrm{e}-05 * * \\
(7.26 \mathrm{e}-06)\end{array}$ & $\begin{array}{l}4.46 \mathrm{e}-05 * * \\
(6.64 \mathrm{e}-06)\end{array}$ \\
\hline Tacc & & $\begin{array}{l}-2.40 \mathrm{e}-06^{* *} \\
(4.92 \mathrm{e}-07)\end{array}$ & $\begin{array}{l}-2.58 \mathrm{e}-06^{* *} \\
(4.40 \mathrm{e}-07)\end{array}$ \\
\hline Tgec & & & $\begin{array}{l}-1.62 \mathrm{e}-08^{* *} \\
(2.39 \mathrm{e}-09)\end{array}$ \\
\hline Constant & $\begin{array}{l}13.12 * * \\
(0.00371)\end{array}$ & $\begin{array}{l}13.12 * * \\
(0.00353)\end{array}$ & $\begin{array}{l}13.13 * * \\
(0.00366)\end{array}$ \\
\hline Observations & 181 & 181 & 181 \\
\hline $\begin{array}{l}\text { R-squared } \\
\text { Adj R-squared } \\
\text { F statistics }\end{array}$ & 0.002 & 0.119 & $\begin{array}{l}0.301 \\
0.2889 \\
25.36 * *\end{array}$ \\
\hline
\end{tabular}

Source: Authors' Compilation (2020)

The regression results presented in Table 3 are used to achieve the specific objective one and associated hypothesis. The result revealed that the model is fitted with a value of F- statistics 25.36 which is statistically significant at 5\% significance level. When the R squared is 0.301 and Adj. R squared is 0.2889 . This implies that numbers of confirmed cases of covid-19 in Nigeria, Africa and Global arena can explain $30 \%$ and $28 \%$ of the systematic variation that occurred in the capital market during the period under review, that is January, $1^{\text {st }} 2020$ and June, $30^{\text {th }} 2020$. When the individual confirmed cases causality are: the confirmed cases of Nigeria, continent of Africa and global have adverse and statistically significant connection with the capitalisation market $(-2.71 \mathrm{e}-$ $07),(-2.58 \mathrm{E}-06)$ and $(-1.62 \mathrm{e}-08)$ respectively, at $5 \%$ level of significance. The implication is that, as the numbers of confirmed cases of covid-19 increase, there is decrease in market capitalisation

4.3.2 Regression results of Foreign Exchange Rate and Nigerian, Africa and Global covid-19 Confirmed cases

Table4

\begin{tabular}{llll}
\hline VARIABLES & $\begin{array}{l}\text { (model1) } \\
\text { Usnaira }\end{array}$ & $\begin{array}{l}\text { (model 2) } \\
\text { usnaira }\end{array}$ & $\begin{array}{l}\text { (model 3) } \\
\text { Usnaira }\end{array}$ \\
\hline Tnce & $0.00103^{* *}$ & -0.00156 & $-0.00526^{* *}$ \\
Tacc & $(0.000110)$ & $(0.00176)$ & $(0.00124)$ \\
& & 0.000176 & $0.000247^{* *}$ \\
Tgcc & & $(0.000119)$ & $(8.20 \mathrm{e}-05)$ \\
& & & $6.33 \mathrm{e}-06^{* *}$ \\
Constant & & & $(4.45 \mathrm{e}-07)$ \\
& $372.4^{* *}$ & $372.2^{* *}$ & $367.3 * *$ \\
Observations & $(0.847)$ & $(0.853)$ & $(0.678)$ \\
R-squared & 182 & 182 & 182 \\
Adj R-squrared & 0.326 & 0.334 & 0.688 \\
F-statistics & & & 0.6831 \\
\hline
\end{tabular}

Source: Authors' Compilation (2020)

The regression results in Table 4 form basis to achieve the specific objective two of the study. The foreign exchange rate of US-dollar to Global, Africa and Nigeria confirmed cases of covid-19 and usnaira have positive relationship with each other and statistically significant at 5\% significance level. This means as numbers of confirmed cases increase in the three territories, foreign exchange rate also increase. The overall model fitted with F statistics is 131.06 and statistically significant at 5\% significance level. R-squared and Adj R-squared are 0.688 and 0.6833 respectively. This means $69 \%$ of the systemic variation that occurred in foreign exchange rate can be explained by the confirmed cases of covid-19 in Global, Africa and Nigeria territories. 
4.3.3 Regression result of cases of Nigerian, Africa and Global covid-19 and Crude Oil Price Per Day (copd) Table 5: Regression result of Crude oil price and Nigerian, Africa and Global covid-19 Confirmed cases

\begin{tabular}{llll}
\hline VARIABLES & $\mathbf{( 1 )}$ & $\mathbf{( 2 )}$ & $\begin{array}{l}\mathbf{( 3 )} \\
\text { Copd }\end{array}$ \\
\hline Tncc & Copd & Copd & $0.0140^{* *}$ \\
Tacc & -0.000158 & $0.00978^{* *}$ & $(0.00196)$ \\
& $(0.000157)$ & $(0.00241)$ & $-0.000756^{* *}$ \\
Tgcc & & $-0.000674^{* *}$ & $(0.000130)$ \\
& & $(0.000163)$ & $-7.23 \mathrm{e}-06^{* *}$ \\
Constant & & & $(7.03 \mathrm{e}-07)$ \\
& & & $44.74^{* *}$ \\
Observations & $38.48^{* *}$ & $39.16^{* *}$ & $(1.072)$ \\
R-squared & $(1.203)$ & $(1.164)$ & 182 \\
Adj R squared & 182 & 182 & 0.431 \\
F statistics & 0.006 & 0.092 & 0.4210 \\
\hline
\end{tabular}

\section{Source: Authors' findings (2020)}

The regression results presented in Table 5 are used in achieving the specific objective three. The Table 5 shows the regression results of confirmed cases of covid-19 and crude oil price per day. The model is fitted with the F statistics of 44.87 and statistically significant at 5\% level of significance. The confirmed cases of covid-19 in the global arena, Africa and Nigeria can explain systematic variation in the crude oil price per day by $43 \%$ and $42 \%$ after R-squared have been adjusted for degree of freedom. Nigeria, Africa and global confirmed cases of covid-19 have adverse relationship with crude oil price per day and statistically significant at $5 \%$ level of significance. This implies that as the confirmed cases of covid-19 increase then the crude oil price reduces.

\subsection{CONCLUSION}

The emergence of the novel covid-19 has devastated and distorted the global economy from the normal norms. This necessitated an empirical enquiry into the aftermath of this pandemic on Nigerian economy by dissecting the impact of covid-19 in Global, African and Nigeria territories on the capital market, foreign exchange and crude oil price using daily data record. The result shows that confirmed cases of covid-19 have an indirect influence on the market capitalization of Nigerian capital market. This implies that as the numbers covid-19 increased the trend of the capital market also deteriorated. That is, the Nigeria, Africa and Global confirmed cases of covid-19 results revealed an indirect nexus among them. This means as the numbers of infected patients or citizens increased there is a downward trend at the capital market. This means that the confirmed cases in these territories have an adverse effect on the capital market.

Nigerian economy is importation based economy that relied heavily on foreign exchange to swap for the local currency naira for international trading. During the period under review the fluctuation of these exchange could not be insusceptible or immune against devastating effect of novel covid-19. The study revealed that as the numbers of confirmed cases of covid-19 of Nigeria, Africa and global arena progressively rising, foreign exchange of $\$ 1$ also progressively skyrocketing. This has a negative effect on naira currency against $\$ 1$. Put differently, Nigeria domestic currency is adversely affected at the detriment of $\$ 1$. The devastating effect of covid-19 on crude oil price per day is also colossal. The confirmed cases in Global, Africa and Nigeria territories had an adverse effect on crude oil price. As the confirmed cases increase, all things being equal, the crude oil price per day is plummeting.

We recommend that bailout funds should be made available to financial institution stakeholders and funds in foreign exchange reserve accounts should be used to hedge foreign exchange fluctuations and funds in excess crude oil accounts should be used to cushion the effect of fall in crude oil price.

\section{References}

Albulescu, C. (2020a). Coronavirus and oil price crash. Available at SSRN 3553452. Or https://www.researchgate.net/publication/340048338_Coronavirus_and_Oil_Price_Crash

Albulescu, C. (2020b). Do COVID-19 and crude oil prices drive the US economic policy uncertainty?. arXiv preprint arXiv:2003.07591.

Akinkunmi, M. A. (2007). An Empirical Investigation of The Real Exchange Rate Impact on Economic Activities: The Case of Nigeria. Available at SSRN 968708.

Adeniran, J. O., Yusuf, S. A., \& Adeyemi, O. A. (2014). The impact of exchange rate fluctuation on the Nigerian economic growth: An empirical investigation. International journal of Academic Research in Business and Social sciences, 4(8), 224.

Baker, S. R., Bloom, N., Davis, S. J., Kost, K. J., Sammon, M. C., \& Viratyosin, T. (2020). The unprecedented 
stock market impact of COVID-19 (No. w26945). National Bureau of Economic Research.

Benson, U. O \& Victor, E. O (2012). Real exchange rate and macroeconomic performance: testing for the Balassa - Samuelson hypothesis in Nigeria, International Journal of Economics and Finance,4(2):127-134. https://www.google.com/url? sa=t\&rct=j\&q=\&esrc=s\&source=web\&cd=1\&cad=rja\&ua

Ewa A (2011) in Asher O. J (2012). The Impact Of Exchange Rate Fluctuation On The Nigeria Economic Growth (1980 - 2010). Unpublished B.Sc Thesis of Caritas University Emene, Enugu State, Nigeria.

Ezigbo, Onyebuchi; Ifijeh, Martins (1 February 2020). "Coronavirus Spread: WHO Lists Nigeria Among High Risk Countries". This Day Newspaper.

Gopinath, G. (2020). 3 Limiting the economic fallout of the coronavirus with large targeted policies. Mitigating the COVID Economic Crisis: Act Fast and Do Whatever, 41.

Hoque, A., Shikha, F. A., Hasanat, M. W., Arif, I., \& Hamid, A. B. A. (2020). The effect of Coronavirus (COVID19) in the tourism industry in China. Asian Journal of Multidisciplinary Studies, 3(1), 52-58.

Ifijeh, Martins (31 January 2020). "FG Sets up Coronavirus Preparedness Group". This Day Newspaper. Retrieved 10 March 2020.

Jongbo, O. C. (2014). The impact of real exchange rate fluctuation on industrial output in Nigeria. Journal of Policy and Development Studies, 289(1849), 1-11.

Kingsly, K., \& Henri, K. (2020). COVID-19 and Oil Prices. Available at SSRN 3555880.

Maijama'a, R., Musa, K. S., Isah, A. A., \& Adamu, S. (2020). Analysis of the Impact of Coronavirus Outbreak on the Nigerian Economy. American Journal of Environmental and Resource Economics, 5(2), 39-43.

Nicola, M., Alsafi, Z., Sohrabi, C., Kerwan, A., Al-Jabir, A., Iosifidis, C., ... \& Agha, R. (2020). The socioeconomic implications of the Coronavirus and COVID-19 pandemic: A Review. International Journal of Surgery.

Nseobot, I. R., Ahmed Soomro, M., Effiong, A. I., Muhiyuddin Solangi, G., Idongesit, M., \& Ali Soomro, F. (2020). COVID-19: A Situation Analysis of Nigeria's Economy. Abere, OJ, Survival Analysis of Novel Corona Virus (2019-Ncov) Using Nelson Aalen Survival Estimate. International Journal of Business Education and Management Studies, 3(1), P30-40.

Odunsi, W. (28 January 2020). "Coronavirus: Nigeria announces preventive measures, releases numbers". Daily Post Nigeria. Retrieved 10 March 2020.

Onali, E. (2020). Covid-19 and stock market volatility. Available at SSRN 3571453.

Osigwe, A. C. (2015). Exchange rate fluctuations, oil prices and economic performance: Empirical evidence from Nigeria. International Journal of Energy Economics and Policy, 5(2), 502-506.

Owusu, E. L. (2016). Stock market and sustainable economic growth in Nigeria. Economies, 4(4), 25.

Ronco, C., Reis, T., \& De Rosa, S. (2020). Coronavirus epidemic and extracorporeal therapies in intensive care: si vis pacem para bellum. Blood Purification, 49(3), 255-258.

Sheresheva, M. Y. (2020). Coronavirus and tourism. Population and Economics, 4, 72.

Sharif, A., Aloui, C., \& Yarovaya, L. (2020). COVID-19 Pandemic, Oil Prices, Stock Market and Policy Uncertainty Nexus in the US Economy: Fresh Evidence from the Wavelet-Based Approach. Oil Prices, Stock Market and Policy Uncertainty Nexus in the US Economy: Fresh Evidence from the Wavelet-Based Approach (April 13, 2020).

Takahashi, H., \& Yamada, K. (2020). When Japanese Stock Market Meets COVID-19: Impact of Ownership, Trading, ESG, and Liquidity Channels. Trading, ESG, and Liquidity Channels (April 16, 2020).

Villarreal-Samaniego, D. (2020). COVID-19, Oil Prices, and Exchange Rates: A Five-Currency Examination. Oil Prices, and Exchange Rates: A Five-Currency Examination (May 4, 2020). : https://ssrn.com/abstract=3593753 or http://dx.doi.org/10.2139/ssrn.3593753

Yilmazkuday, H. (2020). COVID-19 effects on the S\&P 500 index. Available at SSRN 3555433. 